\title{
PENGARUH KECERDASAN EMOSIONAL TERHADAP KEMAMPUAN MEMECAHKAN MASALAH MATEMATIKA SISWA KELAS IV SDN SEKECAMATAN KEBUMEN TAHUN AJARAN 2020/2021
}

\author{
Ngaenu Rofiqoh', Rokhmaniyah ${ }^{2}$, Ngatman $^{3}$ \\ Universitas Sebelas Maret \\ ngaenurofiqoh16@gmail.com
}

\section{Article History}

accepted $1 / 11 / 2021$

\begin{abstract}
The research aimed to determine the effect of emotional intelligence on the ability to solve math problems and to measure the contribution of emotional intelligence on the ability to solve math problems to fourth grade students of public elementary schools in Kebumen Sub-district in academic year of 2020/2021. The research was correlational quantitative method. The population were 1400 fourth grade students and the samples were 332 fourth grade students in Kebumen Sub-district. Data collection techniques were questionnaires and tests. Data will be analyzed using regression analysis, correlation analysis, and effective contribution. The results showed that there was an effect of emotional intelligence on the ability to solve math problems to fourth grade students of public elementary schools in Kebumen Sub-district with the value of Sig. $0.000<0.05$. It meant that the higher student's emotional intelligence, the higher student's ability to solve math problems, and vice versa. The adjusted $R$ square of emotional intelligence on the ability to solve math problems was $13.2 \%$ and the remaining $86.8 \%$ was influenced by other factors.
\end{abstract}

Keywords: emotional intelligence, ability to solve math problems

\begin{abstract}
Abstrak
Penelitian ini bertujuan untuk mengetahui adanya pengaruh kecerdasan emosional terhadap kemampuan memecahkan masalah matematika dan menghitung besarnya sumbangan efektif kecerdasan emosional terhadap kemampuan memecahkan masalah matematika siswa kelas IV SDN se-Kecamatan Kebumen tahun ajaran 2020/2021. Penelitian ini merupakan penelitian kuantitatif dengan metode penelitian korelasi. Populasi dalam penelitian ini berjumlah 1.400 siswa dengan jumlah sampel 332 siswa kelas IV SDN se-Kecamatan Kebumen. Teknik pengumpulan data yang digunakan dalam penelitian ini adalah angket dan tes, data akan dianalisis menggunakan analisis regresi, analisis korelasi, dan sumbangan efektif. Hasil penelitian ini menunjukkan bahwa terdapat pengaruh kecerdasan emosional terhadap kemampuan memecahkan masalah matematika siswa kelas IV SDN se-Kecamatan Kebumen sebesar $13.2 \%$ dengan nilai Sig. 0,000 $<0,05$, artinya semakin tinggi kecerdasan emosional siswa, maka akan semakin tinggi pula kemampuan memecahkan masalah matematika siswa, dan begitupun sebaliknya. Sumbangan efektif variabel kecerdasan emosional terhadap kemampuan memecahkan masalah matematika yaitu sebesar $13,2 \%$ dan sisanya sebesar $86,8 \%$ dipengaruhi oleh faktor lain.
\end{abstract}

Kata kunci: kecerdasan emosional, kemampuan memecahkan masalah matematika 


\section{PENDAHULUAN}

Matematika merupakan salah satu muatan yang diajarkan pada setiap jenjang pendidikan. Seperti pada Peraturan Pemerintah Nomor 32 Tahun 2013 tentang standar nasional pendidikan tertera bahwa matematika merupakan suatu muatan umum yang ada di setiap jenjang SD, SMP dan SMA atau sederajat. Marta (2018) menyatakan bahwa dalam dunia pendidikan, matematika termasuk dalam salah satu bidang studi yang memegang peran penting, baik dalam kehidupan sehari-hari maupun dalam perkembangan ilmu pengetahuan dan teknologi. Hal tersebut selaras dengan pendapat dari Hudojo (Amir, 2015) menyatakan bahwa pendidikan matematika yang ada dari jenjang pendidikan dasar sampai pendidikan lanjut memiliki fungsi untuk mempersiapkan para ahli pengetahuan, teknologi dan perencanaan kota. Berdasarkan pendapat tersebut menandakan bahwa matematika merupakan salah satu mata pelajaran yang penting untuk dipelajari agar dapat menghasilkan siswa yang andal dalam menghadapi perubahan zaman melalui penguasaan matematika. Sehingga diperlukannya perhatian dan penanganan yang serius terhadap mata pelajaran matematika.

Selama ini matematika sering menjadi momok bagi para siswa karena menganggap bahwa mata pelajaran matematika adalah mata pelajaran yang sulit, penuh dengan rumus dan angka-angka (Hidayati, 2017). Padahal kenyataannya pada mata pelajaran matematika tidak hanya mengenai rumus dan angka-angka. Melainkan mengenai berbagai pembelajaran yang dapat berguna dalam kehidupan sehari-hari. Hal tersebut selaras dengan pendapat Wahyudi (2015) yang menyatakan bahwa kelas matematika merupakan tempat menemukan ide-ide dan konsep matematika melalui penyelidikan masalah nyata dan matematika sebagai kegiatan manusia yang mulanya dari pemecahan masalah. Fungsi matematika yaitu mengembangkan berpikir nalar melalui penyelidikan, eksplorasi, dan eksperimen, sebagai alat pemecahan masalah melalui pola pikir dan model matematika serta sebagai alat komunikasi melalui simbol, tabel, grafik, diagram, dalam menjelaskan gagasan. Selain itu berdasarkan Permendikbud No. 57 tahun 2014 tentang kurikulum SD, matematika dapat didefinisikan sebagai studi dengan logika yang ketat dari topik seperti kuantitas, struktur, ruang, dan perubahan. Matematika merupakan tubuh pengetahuan yang dibenarkan (justified) dengan argumentasi deduktif, dimulai dari aksioma-aksioma dan definisi-definisi.

Banyak hal yang dapat diperoleh dari belajar matematika. Salah satunya yaitu belajar mengenai pemecahan masalah. Pembelajaran matematika di sekolah dasar tidak hanya terarah pada peningkatan kemampuan berhitung siswa, melainkan juga terarah pada peningkatan kemampuan siswa dalam pemecahan masalah (Problem Solving), baik dalam permasalahan mengenai matematika ataupun masalah lain yang secara kontekstual menggunakan matematika dalam proses pemecahannya (Inda, Ahmad \& Yannika, 2019).

Siswa sekolah dasar berada pada tahap perkembangan kognitif yang berbeda dengan jenjang sekolah berikutnya. Dalam perkembangan intelektual menurut Piaget, siswa sekolah dasar sebagian besar sedang berada di tahap operasional konkret (Ramlah, 2015). Oleh karena itu, proses pembelajaran tidak hanya berfokus pada upaya memberikan pengetahuan sebanyak-banyaknya melainkan juga bagaimana menggunakan pengetahuan yang dimilikinya untuk menghadapi kondisi baru atau memecahkan masalah pada bidang studi yang dipelajarinya.

Berdasarkan hasil survei PISA diperoleh bahwa hanya ada $15,5 \%$ siswa yang mampu menyelesaikan masalah matematika dengan menggunakan prosedur dan strategi pemecahan masalah matematika (Rofiqoh, 2015). Menurut Polya (Yani, Ikhsan \& Marwan, 2016) pemecahan masalah matematika dapat terselesaikan dengan baik melalui empat strategi, yaitu memahami masalah (understanding the problem), menyusun rencana penyelesaian masalah (devising a plan), melaksanakan rencana 
penyelesaian masalah (carrying out the plan), mengecek penyelesaian masalah (looking back).

Kecerdasan emosional merupakan suatu hal yang diperlukan oleh siswa pada pemecahan masalah matematika. Tanpa adanya kecerdasan emosional siswa akan mudah menyerah, tidak mempunya motivasi diri untuk belajar, dan tidak pandai memusatkan perhatian pada materi pelajaran, meskipun sebenarnya ia mampu untuk mempelajarinya. Menurut Goleman kecerdasan intelektual (IQ) hanya menyumbang kira-kira $20 \%$ dalam menentukan prestasi individu, sedangkan $80 \%$ sisanya ditentukan oleh faktor-faktor lain termasuk kecerdasan emosional (Amalia, 2017).

Kecerdasan emosional merupakan suatu kemampuan seseorang dalam mengendalikan emosinya sendiri. Menurut Bedwell kecerdasan emosional akan dapat berpengaruh terhadap seseorang pada pembuatan keputusan, pemecahan masalah, dan cara berinteraksi dengan orang lain serta dalam kreativitas dan inovasi dalam lingkungan Pendidikan (Amalia, 2017). Apabila ketika siswa dihadapkan pada suatu masalah dan dapat menyelesaikannya dengan baik, hal tersebut karena ia dapat mengkomunikasikan emosinya dengan efektif dan mampu mengontrol emosinya dengan baik saat berada di situasi krisis masalah. Namun apabila siswa tersebut tidak bisa mengontrol emosinya maka akan mengalami kesulitan dalam mengatasi masalah yang dihadapinya, baik masalah yang berhubungan dengan pembelajaran, pekerjaan ataupun hal yang lain (Prafitriani, dkk., 2019).

Kecerdasan emosional seorang siswa dapat dilihat melalui ciri-ciri kecerdasan emosional itu sendiri. Goleman mengungkapkan seseorang dengan kecerdasan emosional memiliki ciri-ciri keterampilan kesadaran diri, mengelola emosi, motivasi diri, empati dan keterampilan sosial (Maftukhah, 2018).

Berdasarkan uraian tersebut peneliti ingin mengetahui ada tidaknya pengaruh kecerdasan emosional terhadap kemampuan pemecahan masalah matematika pada siswa kelas IV SDN di Kecamatan Kebumen melalui penelitian kuantitatif dengan judul "Pengaruh Kecerdasan Emosional terhadap Kemampuan Memecahkan Masalah Matematika Siswa Kelas IV SDN Se-Kecamatan Kebumen tahun ajaran 2020/2021".

\section{METODE}

Penelitian ini merupakan penelitian kuantitatif dengan metode penelitian korelasi. Penelitian korelasi adalah penelitian yang dilakukan oleh peneliti untuk mengetahui tingkat hubungan antara dua variabel atau lebih, tanpa melakukan perubahana atau manipulasi terhadap data yang sudah ada (Arikunto, 2013).

Populasi penelitian ini yaitu siswa kelas IV SDN se-Kecamatan Kebumen sejumlah 1400 siswa, sampel sebanyak 312 siswa, dan sampel yang diperoleh sebanyak 332 siswa di 13 SD Negeri di Kecamatan Kebumen yang dipilih secara acak dengan teknik cluster random sampling dengan bantuan aplikasi Statistical Product and Service Solution (SPSS) versi 21.

Teknik pengumpulan data yang digunakan dalam penelitian ini berupa angket dan tes. Angket digunakan untuk mengumpulkan data kecerdasan emosional dan tes digunakan untuk mengumpulkan data kemampuan memecahkan masalah matematika. Instrumen penelitian ini yaitu angket kecerdasan emosional yang dibagi menjadi indikator kesadaran diri siswa, pengendalian diri siswa, motivasi diri siswa, empati, keterampilan sosial. Selanjutnya, tes kemampuan memecahkan masalah matematika terdiri dari indikator memahami masalah, merencanakan penyelesaian, melaksanakan perencanaan, pemeriksaan kembali proses dan hasil dengan materi kelas IV SD semester gasal tahun ajaran 2020/2021.

Uji prasyarat data penelitian ini yaitu uji normalitas data dan uji linieritas data. Setelah data memenuhi prasyarat yang ditentukan, data akan dianalisis menggunakan analisis regresi, analisis korelasi, dan sumbangan efektif. 


\section{HASIL DAN PEMBAHASAN}

Penelitian ini dilakukan dengan memberikan angket kecerdasan emosional dan tes kemampuan pemecahan masalah matematika kepada siswa kelas IV di 13 SDN seKecamatan Kebumen. Angket dan tes ini berisi soal yang memuat indikator kemampuan membaca pemahaman dan kemampuan pemecahan masalah matematika sehingga dapat mengukur tinggi rendahnya kecerdasan emosional dan kemampuan pemecahan masalah matematika. Prasyarat data terpenuhi yaitu data berasal dari populasi berdistribusi normal dan terdapat hubungan linear antara kecerdasan emosional dan kemampuan pemecahan masalah matematika. Data hasil penelitian berasal dari data berdistribusi normal yang ditunjukkan dengan nilai signifikansi kecerdasan emosional 0,200 dan kemampuan pemecahan masalah matematika 0,100 . Kedua nilai signifikansi data menunjukkan nilai $>0,05$ sehingga data tersebut berasal dari populasi berdistribusi normal. Data dikatakan terdapat hubungan linear antara variabel $X$ dan $Y$ jika Sig. Deviation from Linearity $>0,05$. Nilai Sig. Deviation from Linearity yaitu 0,139>0,05 sehingga terdapat hubungan linear antara kecerdasan emosional dengan kemampuan pemecahan masalah matematika. Setelah uji prasyarat analisis data telah terpenuhi, selanjutnya dilakukan analisis data uji hipotesis. Tabel 1 akan memperlihatkan hasil analisis regresi kecerdasan emosional terhadap kemampuan memecahkan masalah matematika.

Tabel 1. Hasil Analisis Regresi Kecerdasan Emosional terhadap Kemampuan Memecahkan Matematika Model Summary

\begin{tabular}{lccccc}
\hline Model & $R$ & $R$ Square & $\begin{array}{l}\text { Adjusted } \\
\text { Square }\end{array}$ & \multicolumn{2}{c}{$\begin{array}{l}\text { Std. Error of } \\
\text { the Estimate }\end{array}$} \\
\hline 1 & & $.363^{\mathrm{a}}$ & .132 & .129 & 12.421 \\
\hline
\end{tabular}

a. Predictors: (Constant), Kecerdasan Emosional

Berdasarkan uji regresi yang telah dilakukan, pada tabel 1 dapat diketahui bahwa besarnya nilai korelasi/ hubungan $(R)$ yaitu sebesar 0,363 , dengan $r$ tabel sebesar 0,107 maka nilai $r$ hitung $(0,363)>r$ tabel $(0,107)$ artinya terdapat hubungan antara kecerdasan emosional dan kemampuan memecahkan masalah matematika dengan koefisien korelasi berada pada tingkat hubungan moderat/sedang menurut tabel pedoman interpretasi koefisien korelasi versi De Vaus. Dari output tersebut diperoleh koefisien determinasi ( $R$ Square) sebesar 0,132, yang artinya kontribusi kecerdasan emosional terhadap kemampuan memecahkan masalah matematika adalah sebesar 0,132 x 100\% $=13,2 \%$, atau dengan kata lain $13,2 \%$ pengaruh kemampuan memecahkan masalah matematika ditentukan oleh kecerdasan emosional, sedangkan $86,8 \%$ dipengaruhi oleh variabel lain yang tidak diteliti. Hal tersebut sejalan dengan pendapat Titi (2020) yang menyatakan bahwa kecerdasan emosional memiliki pengaruh yang signifikan terhadap kemampuan memecahkan masalah matematika. Tabel 2 akan memperlihatkan nilai koefisien regresi kecerdasan emosional terhadap kemampuan memecahkan masalah matematika.

Tabel 2. Koefisien Regresi

\begin{tabular}{|c|c|c|c|c|c|}
\hline \multicolumn{6}{|c|}{ Coefficients $^{a}$} \\
\hline \multirow[t]{2}{*}{ Model } & \multicolumn{2}{|c|}{$\begin{array}{l}\text { Unstandardized } \\
\text { Coefficients }\end{array}$} & $\begin{array}{l}\text { Standardized } \\
\text { Coefficients }\end{array}$ & $T$ & Sig. \\
\hline & $B$ & Std. Error & Beta & & \\
\hline 1 (Constant) & 24.573 & 5.579 & & 4.405 & .000 \\
\hline
\end{tabular}




\begin{tabular}{llllll}
$\begin{array}{l}\text { Frekuensi } \\
\text { Belajar }\end{array}$ & .514 & .073 & .363 & 7.072 & .000 \\
\hline
\end{tabular}

a. Dependent Variable: Pemecahan Masalah

Tabel 2 tersebut menginformasikan model persamaan regresi yang diperoleh dengan koefisien konstanta dan koefisien variabel yang ada di kolom Unstandardized Coefficients $B$. Sehingga diperoleh model persamaan regresi linier sederhana: $Y^{\prime}=$ $24,573+0,514 X$

Penelitian ini bertujuan untuk mengetahui adanya pengaruh kecerdasan emosional terhadap kemampuan memecahkan masalah matematika siswa kelas IV SDN seKecamatan Kebumen Tahun Ajaran 2020/2021. Berdasarkan output di atas dapat diketahui bahwa nilai signifikansi variabel frekuensi belajar sebesar 0,000 , karena nilai signifikansi lebih kecil dari $0,05(0,000<0,50)$ maka tolak $\mathrm{H}_{0}$, sehingga terima $\mathrm{H}_{1}$ yang berbunyi bahwa ada pengaruh antara kecerdasan emosional dengan kemampuan memecahkan masalah matematika siswa kelas IV SDN se-Kecamatan Kebumen tahun ajaran 2020/2021.

Besarnya pengaruh kecerdasan emosional terhadap kemampuan memecahkan masalah matematika dihitung menggunakan sumbangan efektif. Sebelum melakukan perhitungan sumbangan efektif, peneliti terlebih dahulu mencari nilai koefisien determinasi, dan sumbangan relatif. Koefisien determinasi pada penelitian ini menggunakan rumus menurut Riduwan dan Sunarto (2013) dapat dicari menggunakan rumus sebagai berikut:

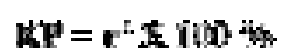

Di mana nilai $r$ telah diketahui yaitu $r=0,363$

$$
\begin{aligned}
\mathrm{KP} & =(0,363)^{2} \times 100 \% \\
& =0,132 \times 100 \% \\
& =13,2 \%
\end{aligned}
$$

Berdasarkan hasil perhitungan di atas, didapatkan nilai koefisien determinasi dalam persen yaitu $13,2 \%$, dengan koefisien determinasi sebesar 0,132 . Setelah diketahui nilai koefisien determinasi $\left(R^{2}\right)$, maka analisis selanjutnya yaitu mencari sumbangan relatif. Sumbangan relatif pada penelitian ini menggunakan rumus sebagai berikut.

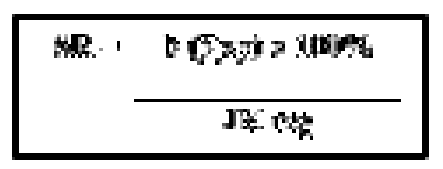

Peneliti menggunakan analisis regresi dengan aplikasi SPSS versi 21 untuk mencari nilai b dan JK reg, sedangkan untuk mencari jumlah xy peneliti menggunakan aplikasi MS. Excel. Hasil perhitungan $\sum x y$ yaitu 15008,55. Tabel 3 akan memperlihatkan hasil analisis uji regresi.

Tabel 3. Hasil Analisis Nilai JK reg pada Uji Regresi ANOVA ${ }^{\mathrm{a}}$ 


\begin{tabular}{lllllll} 
Model & & $\begin{array}{l}\text { Sum } \\
\text { Squares }\end{array}$ & of $d f$ & $\begin{array}{l}\text { Mean } \\
\text { Square }\end{array}$ & $F$ & Sig. \\
\hline \multirow{3}{*}{1} & Regression & 7715.856 & 1 & 7715.856 & 50.013 & $.000^{\mathrm{b}}$ \\
& Residual & 50911.286 & 330 & 154.227 & & \\
& Total & 58627.142 & 331 & & & \\
\hline
\end{tabular}

a. Dependent Variable: Pemecahan Masalah

b. Predictors: (Constant), Kecerdasan Emosional

Berdasarkan tabel 2 dan 3, didapatkan nilai JK reg sebesar 7715,856 dan nilai b sebesar 0,514 , maka sumbangan relatif dapat dicari menggunakan rumus:

$\mathrm{SR}=\underline{0,514(15008,55) \times 100 \%}$

7715,856

$\mathrm{SR}=0,999 \times 100 \%$

$\mathrm{SR}=99,9 \% \approx 100 \%$

Analisis selanjutnya yaitu mencari sumbangan efektif. Dari perhitungan di atas didapatkan nilai $S R$ sebesar $100 \%$ dan $R^{2}$ sebesar 0,132 . Maka SE dapat dicari menggunakan rumus sebagai berikut:

$\mathrm{SE}=(\mathrm{SR}) \times(\mathrm{R} 2)$

$\mathrm{SE}=100 \% \times 0,132$

SE $=13,2 \%$

Berdasarkan hasil perhitungan di atas, dapat diketahui bahwa sumbangan efektif dari kecerdasan emosional dapat berperan dalam meningkatkan kemampuan memecahkan masalah matematika sebesar $13,2 \%$, sedangkan sisanya sebesar $86,6 \%$ dipengaruhi oleh faktor lain. Hasil penelitian sesuai dengan penelitian yang dilakukan oleh Inda, dkk., (2019) menunjukkan adanya korelasi yang signifikan antara kecerdasan emosional dengan kemampuan menyelesaikan masalah matematika. Pengaruh dapat terjadi karena adanya hubungan antar variabel. Hal ini dibuktikan dengan nilai hasil koefisien korelasi sebesar 0,792 yang artinya semakin tinggi kecerdasan emosional siswa, maka semakin baik pula kemampuan menyelesaikan masalah siswa tersebut begitu pun sebaliknya.

Selain itu hasil penelitian ini juga diperkuat dengan penelitian yang dilakukan oleh Brahmansyah (2019) yang menunjukkan adanya korelasi yang signifikan dan memiliki pengaruh yang kuat antara kecerdasan emosional terhadap kemampuan memecahkan masalah matematika hal ini ditunjukkan dengan thitung = jauh lebih besar pada ttabel yaitu 1,980 atau thitung 3,275 $>1,980$ pengaruh positif dari kecerdasan emosional siswa terhadap kemampuan memecahkan masalah matematika siswa sebesar 5,76\% sedangkan sisanya $94,24 \%$ dipengaruhi oleh faktor lainnya.

Berdasarkan uraian di atas, dapat disimpulkan bahwa hasil penelitian ini telah sesuai dengan teori yang ada dan didukung pula dengan penelitian yang relevan, maka hasil penelitian ini adalah ada pengaruh positif antara kecerdasan emosional terhadap kemampuan memecahkan masalah matematika siswa kelas IV SDN se-Kecamatan Kebumen tahun ajaran 2020/2021. 


\section{SIMPULAN}

Berdasarkan hasil penelitian mengenai kecerdasan emosional dan kemampuan memecahkan masalah matematika siswa kelas IV SDN se-Kecamatan Kebumen tahun ajaran 2020/2021 dapat ditarik kesimpulan sebagai berikut.

1. Kecerdasan emosional berpengaruh terhadap kemampuan memecahkan masalah matematika siswa kelas IV SDN se-Kecamatan Kebumen tahun ajaran 2020/2021 sebesar $13,2 \%$. Semakin tinggi kecerdasan emosional siswa, maka akan semakin tinggi pula kemampuan memecahkan masalah matematika siswa, dan semakin rendah kecerdasan emosional siswa maka semakin rendah pula kemampuan memecahkan masalah matematika pada siswa.

2. Sumbangan efektif variabel kecerdasan emosional terhadap kemampuan memecahkan masalah matematika siswa kelas IV SDN se-Kecamatan Kebumen tahun ajaran 2020/2021 yaitu sebesar $13,2 \%$ dan sisanya sebesar $86,6 \%$ dipengaruhi oleh faktor lain.

\section{DAFTAR PUSTAKA}

Amalia, W. (2017). Hubungan Antara Kecerdasan Emosional dengan Kemampuan Menyelesaikan Masalah pada Siswa SMA Aisyiyah 1 Palembang. Skripsi Tidak Dipublikasikan, Universitas Islam Negeri Raden Fatah.

Amir, M. F. (2015). Pengaruh Pembelajaran Kontekstual Terhadap Kemampuan Pemecahan Masalah Matematika Siswa Sekolah Dasar. Prosiding Seminar Nasional Pendidikan, hlm. 34-42. Sidoarjo: Fakultas Keguruan dan IImu Pendidikan Universitas Muhammadiyah Sidoarjo.

Arikunto, S. (2013). Prosedur Penelitian Suatu Pendekatan Praktik. Jakarta: Rineka Cipta.

Brahmansyah, R. (2021). Pengaruh Kecerdasan Emosional dan Minat Belajar terhadap Kemampuan Pemecahan Masalah Matematika. ALFARISI: Jurnal Pendidikan MIPA, 2(3).

Hidayati, A. U. (2017). Melatih Keterampilan Berpikir Tingkat Tinggi Dalam Pembelajaran Matematika Pada Siswa Sekolah Dasar. Terampil: Jurnal Pendidikan Dan Pembelajaran Dasar, 4(2), 143-156.

Inda, I. R., Ahmad, Y., \& Yannika, N. (2019) Hubungan Kecerdasan Emosional Terhadap Kemampuan Pemecahan Masalah Matematika Siswa Kelas V SD Muhammadiyah I Remu Sorong. Jurnal PAPEDA, 1(1), 23-28.

Maftukhah, N. A. (2019). Analisis Kecerdasan Emosional Siswa Terhadap Kemampuan Problem Solving Matematika Siswa Sekolah Menengah Pertama. Al-Hikmah: Jurnal Kependidikan Dan Syariah, 6(2), 1-10.

Prafitriani, S., Umanailo, M. C. B., Indrayani, N., Lisaholit, S., \& Chamidah, D. (2019). pengaruh kecerdasan emosional terhadap hasil belajar matematika siswa kelas VII SMP Negeri 9 Buru. JISPO: Jurnal IImu Sosial dan IImu Politik, 9(2), 567-580.

Ramlah, R. (2015). Penerapan Teori Perkembangan Mental Piaget Tahap Operasional Konkret Pada Hukum Kekekalan Materi. Judika (JURNAL PENDIDIKAN UNSIKA), 3(2), 218-230.

Riduwan \& Sunarto. (2013). Pengantar Statistika untuk Penelitian Pendidikan, Sosial, Ekonomi, Komunikasi, dan Bisnis. Bandung: Alfabeta.

Rofiqoh, Z. (2015). Analisis Kemampuan Pemecahan Masalah Matematika Siswa Kelas $X$ Dalam Pembelajaran Discovery Learning Berdasarkan Gaya Belajar Siswa. Doctoral dissertation, UNIVERSITAS NEGERI SEMARANG.

Titi Shokhifatul, K. (2020). Pengaruh Kecerdasan Emosional Terhadap Kemampuan Pemecahan Masalah Matematika Siswa Kelas VII MTs Ma'arif NU Kaligiri 
Kecamatan Sirampog Kabupaten Brebes Tahun Pelajaran 2019/2020. (Doctoral dissertation) IAIN Purwokerto.

Wahyudi. (2015). Panduan Pembelajaran Matematika Sekolah Dasar (Untuk Guru dan Calon Guru SD). Surakarta: UNS Press.

Yani, M., Ikhsan, M., \& Marwan, M. (2016). Proses berpikir siswa sekolah menengah pertama dalam memecahkan masalah matematika berdasarkan langkah-langkah Polya ditinjau dari adversity quotient. Jurnal Pendidikan Matematika, 10(1), 43-57. 